\title{
Effect of pyrolisis temperature and time on liquid smoke characteristics
}

\author{
Seri Maulina ${ }^{1,2, *}$, Rizki Amalia ${ }^{1}$, and Ekanzha R Kamny ${ }^{1}$ \\ ${ }^{1}$ Department of Chemical Enginnering, Faculty of Engineering, Universitas Sumatera Utara, Medan, Indonesia \\ ${ }^{2}$ Sustainable Energy and Biomaterial Center of Excellence, Faculty of Engineering, Universitas Sumatera Utara, Medan, Indonesia
}

\begin{abstract}
Oil palm frond is a lignocellulose material, by pyrolysis, it will produce liquid smoke which have many advantages because of the compounds, such as acetic acid, carbonyls and phenolics contained in it. The pyrolysis of oil palm fronds in this study carried out at temperatures $400{ }^{\circ} \mathrm{C}, 500{ }^{\circ} \mathrm{C}$, and $600{ }^{\circ} \mathrm{C}$ for 40 minutes, 90 minutes, and 120 minutes. There were 3 parameters observed in this study, they were acetic acid, phenolics and carbonyl contents which were analyzed by GC-MS instrument. The results of the study showed that the different temperatures and times of pyrolysis affected the content of chemical components in liquid smoke and acetic acid was the most dominant component obtained in the liquid smoke. The highest acetic acid content in the liquid smoke obtained was $92,30 \%$ at pyrolysis temperature of $500{ }^{\circ} \mathrm{C}$ for 120 minutes. Meanwhile, the highest total phenolic content obtained was $7,32 \%$ at pyrolysis temperature of $600{ }^{\circ} \mathrm{C}$ for 120 minutes and the highest carbonyl content obtained was $32,56 \%$ at the pyrolysis temperature of $400{ }^{\circ} \mathrm{C}$ for 60 minutes
\end{abstract}

\section{Introduction}

In the oil palm plantation, the major biomass wastes are trunks and oil palm fronds [1]. OPF consists primarily of lignocellulosic components, i.e, cellulose $(49,8 \%)$, hemicellulose $(23,5 \%)$ and lignin $(20,5 \%)$ [2-4]. The rising consciousness on the environmental implications has led to the research on alternative biochemical approach to utilize OPF as an alternative material for pyrolysis to produce liquid smoke. The use of organic materials from waste and agricultural by-products to produce liquid smoke also increase economic and social value added [5].

Pyrolysis is a decomposition of organic materials which involves rapid in heating in absence of oxygen which results in production of liquid, gaseous and charcoal products $[6,7]$. The percentage at which these products being produced is always different depending on the type of pyrolysis, biomass used and the process parameters such as pre-treatment condition, reaction temperature and heating rate [8].

Liquid smoke is a product obtained from condensation of vapour produced during pyrolysis which contains oxidized organic compounds, such as ketone, aldehyde, phenol, and carboxylic acid [3, 9]. These compounds act as antioxidant and antibacterial properties, as well as its specific flavor and odour in liquid smoke [10]. Liquid smoke can be used as natural preservative for food or food additive that imparts a smoked flavor and aroma to meats, poultry and seafood. It also can be used as latex coagulant and as biosepticide to reduce termites impact on wood [11, 12].

Raw material type along with pyrolysis operation condition can influence on chemical and physical characteristics of liquid smoke [13]. The purpose of this research is to know the chemical characteristics of liquid smoke produced from OPF which pyrolysized with various times and temperatures level.

\section{Method}

Pyrolysis of oil palm fronds is carried out using a pyrolysis reactor. Oil palm fronds which have been dried then weighed inserted into the pyrolysis reactor and pyrolyzed at temperatures $400{ }^{\circ} \mathrm{C}, 500{ }^{\circ} \mathrm{C}$, and $600{ }^{\circ} \mathrm{C}$ for 60,90 and 120 minutes, then condensed. Condensate in the form of liquid smoke then stored for $2 \times 24$ hours and filtered using filter paper. The parameters analyzed of the liquid smoke are total acid, total phenolic, and total carbonyl contents.

\section{Results and Discussion}

Liquid smoke produced by pyrolysis has black colour. This is because of tar compound that basically has black colour with high molecular weight as the result of degradation (cellulose, hemicellulose and lignin) [13]. Fig. 1 shows the liquid smoke obtained in this study. 


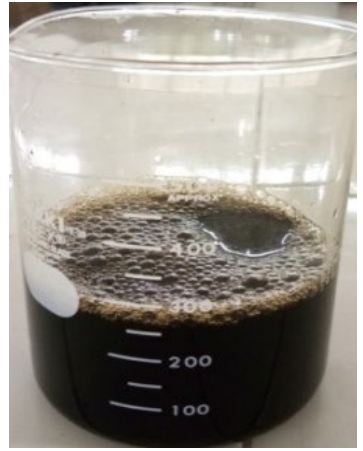

Fig. 1. Liquid smoke produced from oil palm frond

\subsection{Total Phenolic Content}

Phenolic compounds in liquid smoke play major contribution to antibacterial activity and giving smoke aroma in smoked product $[10,12]$. Total phenolic content in the liquid smoke obtained from different pyrolisis temperatures. and times that was determined by GCMS instrument showed in Fig. 2.

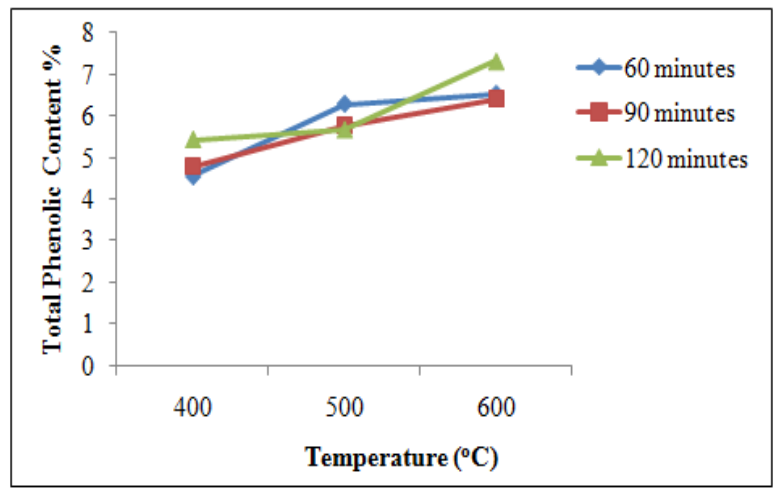

Fig. 2. Total phenolic content in liquid smoke

Generally, total phenolic content will increase with higher in temperature at constant of pyrolysis time. Phenols are obtained from lignin pyrolysis. The quantity and quality of phenol compound that can be found on liquid smoke is related with lignin-content and pyrolysis temperature $[12,13]$. The degradation of lignin usually starts at temperature of $300{ }^{\circ} \mathrm{C}$ [17]. The highest level of phenol compounds obtained was $7.32 \%$ at temperature pyrolysis of $600{ }^{\circ} \mathrm{C}$ for 120 minutes.

\subsection{Acetic Acid Content}

Organic acids which has important role in liquid smoke is acetic acid. It can inhibit bacterial growth by penetrating into the cell wall of bacteria and disrupt the normal physiological function of the cells $[14,18]$. Acetic acid content in the liquid smoke obtained from different pyrolisis temperatures. and times that was determined by GCMS instrument showed in Fig. 3 .

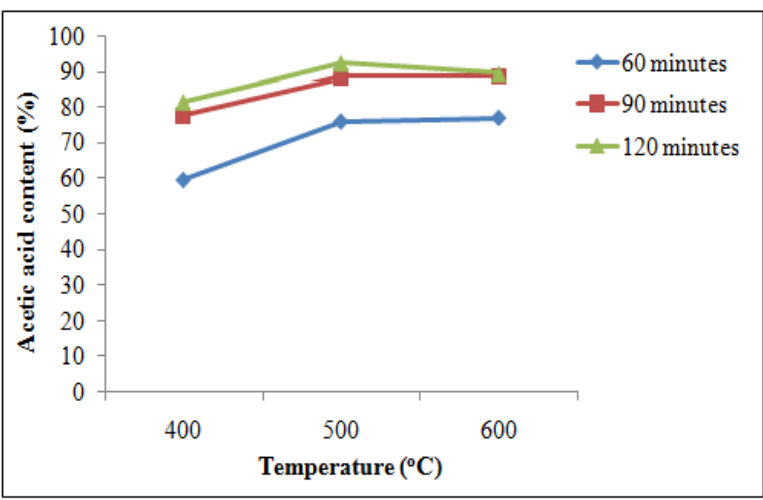

Fig. 3. Acetic acid content in liquid smoke

Cellulose and hemicellulose degradation are the primary sources of carbonyls and carboxylic acids [16]. On pyrolysis, cellulose will be hydrolyzed and produce glucose and further reaction produce acetic acid. Cellulose degradation process occurs on temperatures 280- $320^{\circ} \mathrm{C}$ [13]. Total acid obtained in this study is high due to the cellulose contained in OPF $(40-50 \%)$ [19]. Different temperatures and times affect acetic acid content in liquid smoke. Acetic acid content increse with higher in temperatures and times (Fig. 2). Acetic acid content decrease at pyrolysis temperature of $600{ }^{\circ} \mathrm{C}$ for 120 minutes. At temprature $500{ }^{\circ} \mathrm{C}$ for 120 minutes acetic acid content was $92,30 \%$ and decrease to $89,29 \%$ at pyrolysis temperature of $600{ }^{\circ} \mathrm{C}$ for 120 minutes. Acetic acid decrease at temperature of pyrolysis $600{ }^{\circ} \mathrm{C}$, because this acid degrade to produce $\mathrm{CO}, \mathrm{CH}_{4}$ and $\mathrm{H}_{2}$ [20]. The highest acetic acid obtained was $92,30 \%$ at pyrolysis temperature of $500{ }^{\circ} \mathrm{C}$ for 120 minutes.

\subsection{Total Carbonyl Content}

Carbonyl compunds in liquid smoke contribute to inhibit the growth of bacteria by interfere the use of nutrient of the bacteria in smoked product [21]. Total carbonyl content in the liquid smoke obtained from different pyrolisis temperatures. and times that was determined by GCMS instrument showed in Fig. 4.

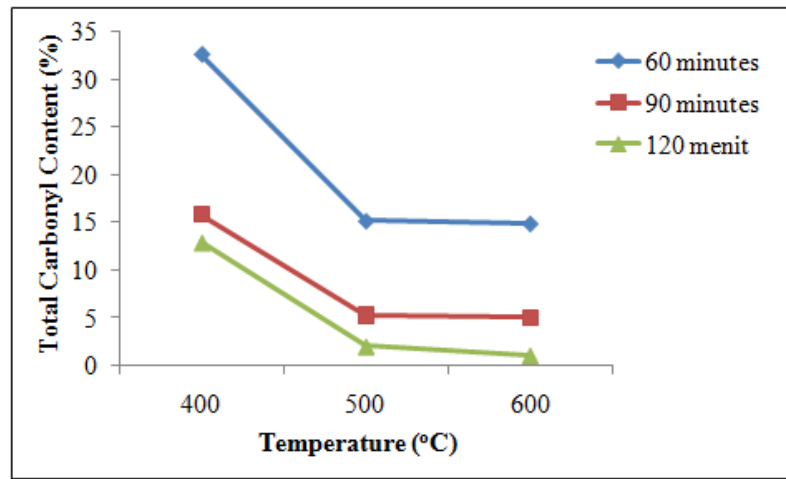

Fig. 4. Analysis result of total carbonyl content in liquid smoke

Primary sources of carbonyls and carboxylic acids are the degradation of cellulose and hemicellulose [16]. High cellulose and hemicellulose contents in raw material will result in high carbonyl content [22]. The 
result of this study shows that total carbonyl contained in liquid smoke tends to decrease along with the rising of temperature and time. The highest carbonyl content obtained was $32.56 \%$ at the pyrolysis temperature of 400 ${ }^{\circ} \mathrm{C}$ for 60 minutes.

\section{Conclusions}

Based on the research, it was found that the variation of pyrolysis operation such as time and temperature level will affect the content of chemical compunds in the liquid smoke obtained. Phenolic and acetic acid content in liquid smoke increase with the rising of temperatures and times, meanwhile carbonyl content is decreased.

\section{References}

1. S. Hassan, L. S. Kee, and H. H. Al-Kayiem, J. Eng. Sci. Technol 8, 703-712 (2013)

2. J. P. Tan, J. M. Jahim, S. Harun, T. Y. Wu, and T. Mumtaz, Int. J. Hydrogen Energy 41, 4896-4906 (2016)

3. A. Gani, H. Husni, A. Baihaqi, and M. Faisal, Int. J. Sci. Eng 7, 65-69 (2014)

4. N. N. Omar, N. Abdullah, I. S. Mustafa, and F. Sulaiman, ASM Sci. J 11, 9-22 (2018)

5. L. S. Hong, D. Ibrahim, and I. C. Omar, Int. J. Biochem. Biotechnol 1, 7-11 (2012)

6. K. C. Sembiring, N. Rinaldi, and S. P. Simanungkalit, Energy Procedia 65, 162-169 (2015)

7. S. Kelkar, C. M. Saffron, K. Andreassi, Z. Li, A. Murkute, D. J. Miller, T. J. Pinnavaia, R. M Kriegel, Appl. Catal. B Environ., 174, 85-95 (2015)

8. F. Sulaiman, N. Abdullah, and A. A. Rahman, AIP Conference Proceedings (2013)

9. M. Faisal, A. Gani, Husni, and H. Daimon, Int. J. GEOMATE 13, 116-120 (2017)

10. S. Saloko, P. Darmadji, B. Setiaji, and Y. Pranoto, Food Biosci 7, 71-79 (2014)

11. M. Faisal, A. R. Yelvia Sunarti, and H. Desvita, Rasayan J. Chem 11, 871-876 (2018)

12. J. I. B. Janairo and D. M. Amalin, Int. Food Res. J 25, 213-216 (2018)

13. K. Budaraga, - Arnim, Y. Marlida, and U. Bulanin, Int. J. Adv. Sci. Eng. Inf. Technol 6, 306 (2016)

14. S. S. Achmadi, N. R. Mubarik, R. Nursyamsi, and P. Septiaji, J. Appl. Sci 13, 401-408 (2013)

15. K. Budaraga, Arnim, Y. Marlida, and U. Bulanin, Int. J. Adv. Sci. Eng. Inf. Technol 6, 306-315 (2016)

16. R. Hadanu and D. A. N. Apituley, Makara J. Sci 20, 95-100 (2016)

17. N. S. David, Chemical modification of lignocellulosic materials (CRC Press, New York, 2017.

18. J. Z. Lombok, B. Setiaji, W. Trisunaryati, and K.
Wijaya, Asian J. Sci. Technol 5, 320-325 (2014)

19. A. W. Noorshamsiana, A. O. Nur Eliyanti, I. Fatiha, and A. A. Astimar, J. Oil Palm Res 29, 512-527 (2017)

20. N. Kholidah, J. Ilmu Kim. dan Terapan 2, 28-33 (2018)

21. N. Montazeri, A. C. M. Oliveira, B. H. Himelbloom, M. B. Leigh, and C. A. Crapo, Food Sci. Nutr 1, 102-115 (2013)

22. M. Lasindrang, Indones. Food Nutr. Prog 14, 59 (2017) 